\title{
Historical perspectives of The American Association for Thoracic Surgery: Edward M. Kent (1908-1970)
}

\author{
Christopher E. Mascio, MD, ${ }^{\mathrm{a}, \mathrm{b}}$ and J. William Gaynor, $\mathrm{MD}^{\mathrm{c}}$
}

Edward Mather Kent, the 49th president of The American Association for Thoracic Surgery (AATS), began his presidential address by expressing his surprise and gratitude for the honor of being selected for such high distinction. He quipped that his address had no title so as to provide an escape should he succumb to the pressure of writing a speech to be given to many of the most important thoracic surgeons in the world. His chosen topic was education of the thoracic surgeon, and he remarked that his words would be best represented by the expression "Tell it like it is, man!"1 The mid to late 1960 s were a time of significant changes in society and in medical education. The Association of American Medical Colleges was gaining increasing influence, Medicare and Medicaid began in 1966, and recommendations from the Citizens Commission on Graduate Medical Education were implemented. All these factors led to changes in training that are still evident today. ${ }^{1}$ These include the creation of the Commission on Graduate Medical Education to review and approve institutions offering medical education and combining internship and residency into a single training period. Dr Kent encouraged his colleagues to embrace these changes and to maintain excellence in training surgeons at academic centers. He stressed that involvement would allow the AATS to maintain participation and leadership in crafting the best thoracic surgical training in the world.

Dr Kent was born in Syracuse, NY, and earned a bachelor's degree from Penn State University in 1929. He attended the College of Medicine at Syracuse University and graduated in 1932. After an internship in Rochester, NY, at St. Mary's Hospital, he received a master's degree from the University of Pennsylvania. This was followed by a residency in surgery at Abington Memorial Hospital, a residency in thoracic surgery at the Connecticut State Sanatorium, and finally a fellowship in thoracic surgery under Evarts Graham (10th AATS president) at Barnes Hospital, Washington University in St Louis, in $1938 .^{2}$

\footnotetext{
From the Department of Pediatric Cardiothoracic Surgery, ${ }^{a}$ Kosair Children's Hospital, Louisville, Ky; the Division of Thoracic and Cardiovascular Surgery, ${ }^{\text {b }}$ Department of Surgery, University of Louisville, Louisville, Ky; and the Division of Cardiothoracic Surgery, ${ }^{\mathrm{c}}$ The Children's Hospital of Philadelphia, Philadelphia, Pa.

Disclosures: Authors have nothing to disclose with regard to commercial support.

Received for publication April 3, 2012; accepted for publication June 8, 2012; available ahead of print July 6, 2012

Address for reprints: J. William Gaynor, MD, Division of Cardiothoracic Surgery, The Children's Hospital of Philadelphia, 34th and Civic Center Blvd, Philadelphia, PA 19104 (E-mail: gaynor@email.chop.edu).

J Thorac Cardiovasc Surg 2012;144:527-9

$0022-5223 / \$ 36.00$

Copyright (c) 2012 by The American Association for Thoracic Surgery http://dx.doi.org/10.1016/j.jtcvs.2012.06.011
}

His first attending appointment was at Glendale Sanitarium in Washington, DC, from 1940 to 1942 . He was eager to serve his country, however, and enlisted in the Navy. He served in the South Pacific Theater and was stationed at Samoa. Subsequently, he was transferred to the staff at Bethesda Naval Hospital. ${ }^{2}$

During his fellowship in St Louis, he had been encouraged by Samuel Harbison to apply for a position at Allegheny General Hospital in Pittsburgh. ${ }^{3}$ After his discharge from the Navy, he was appointed Director of Thoracic Surgery at Allegheny General Hospital, and he was appointed Assistant Professor of Surgery at the University of Pittsburgh in 1946. Dr Kent was a founding member of the Board of Thoracic Surgery. Always dedicated to education of thoracic surgeons, he started the first thoracic residency program in the city of Pittsburgh. ${ }^{3} \mathrm{He}$ achieved the rank of clinical professor in 1957.

Dr Kent authored or coauthored 39 articles and was the first author or senior author of 27. His academic contributions encompassed all areas of thoracic surgery-adult cardiac, general thoracic, and congenital-ranging from nonsutured anastomoses of coronary arteries and the hemoglobin dissociation curve during extracorporeal circulation to solitary pulmonary nodules, surgery for esophageal carcinoma, and coarctation of the aorta in infants and children. His most significant contribution was a manuscript coauthored with Brian Blades (37th AATS president) entitled "Individual Ligation Technique for Lower Lobe Lobectomy," which was presented at the 23rd AATS meeting in Cleveland in $1940 .^{4,5}$ Although there is some debate about who should get credit for performing the first individual ligation for lobectomy, ${ }^{6}$ without question, Blades and Kent are considered the champions of this technique. ${ }^{5}$ This article reported the cases of 18 patients who underwent lobectomy without mortality or empyema. This report was key in changing the technique for lobectomy from one of mass ligation to the technique still used today of hilar dissection and individual ligation and division of the bronchus, pulmonary artery, and pulmonary vein. In 1952, Kent performed Pittsburgh's first closed mitral commissurotomy under hypothermia after traveling to Boston to observe Dwight Harken's technique. ${ }^{3} \mathrm{He}$ also performed the first open heart operation utilizing cardiopulmonary bypass in the city of Pittsburgh in $1957 .^{3}$

The early days of cardiopulmonary bypass were plagued by pulmonary complications and difficulties with myocardial protection. Because of these problems, Dr Kent challenged his younger colleague, George J. Magovern, to create a valve that could be inserted very quickly. ${ }^{7}$ They 

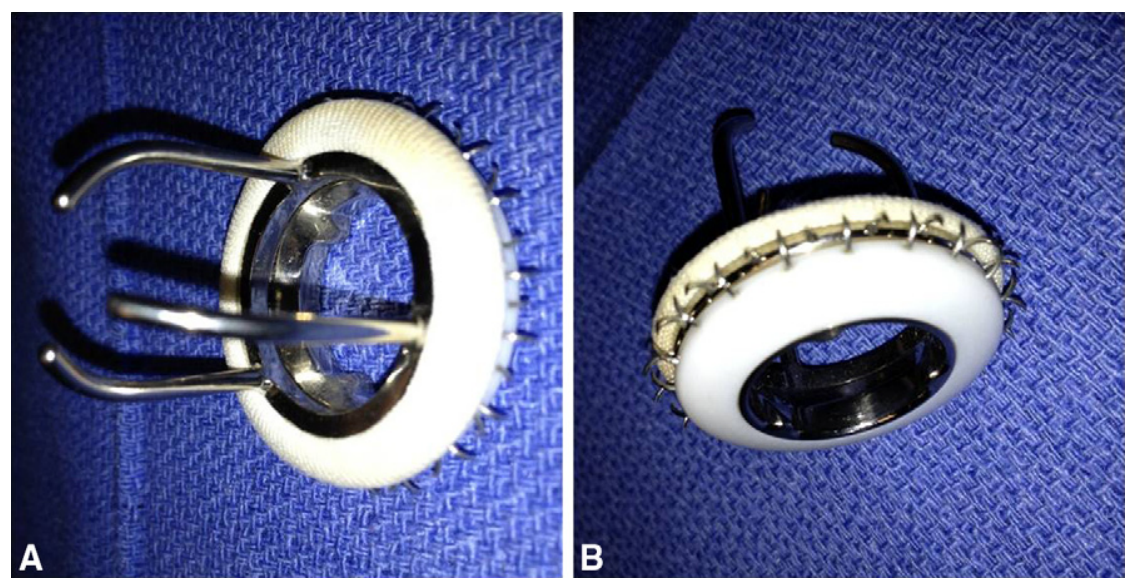

FIGURE 1. Magovern-Cromie sutureless mitral prosthesis with teeth deployed (courtesy of Erle H. Austin III, MD).

conceived and developed a sutureless valve which was first utilized in humans in 1962. The results of the first 10 Magovern-Cromie valve implantations were reported at the AATS Annual Meeting in 1963. Although they never achieved widespread use, these valves have been reported to function perfectly for as long as 42 years. ${ }^{8-10}$ The prosthesis used a caged-ball design like the Starr-Edwards valve, modified by the addition of "teeth" that secured the valve to the annulus (Figure 1, $A$ and $B$ ). The technique for fixation in the mitral position involved the following: (1) excision of the chordae tendineae and most of the anterior leaflet; (2) preservation of the posterior leaflet unless heavily calcified, in which case the posterior leaflet was excised in a fashion that left $0.5 \mathrm{~cm}$ of valve tissue; (3) placement of a circumferential purse-string suture (heavy silk or plastic) into the remaining valve tissue; (4) placement of the valve in the annulus with the insertion device; (5) approximation of the purse-string suture to draw the valve tissue between the plates of the valve; (6) deployment of the teeth of the valve into the rim of valve tissue; (7) tying the purse

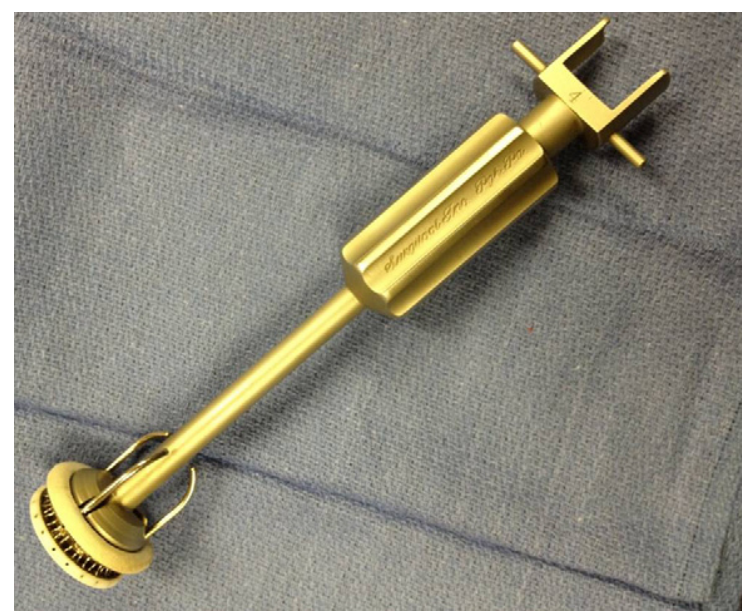

FIGURE 2. Insertion device with sutureless Magovern-Cromie mitral prosthesis (courtesy of Erle H. Austin III, MD). string suture to secure the valve; and (8) removal of the insertion device from the valve (Figure 2). After fixation of the valve, the ball was moistened and squeezed through the steel cage prongs. ${ }^{11}$

Dr Kent has been described as unobtrusive and inconspicuous, and his rounds were lengthy because of his many

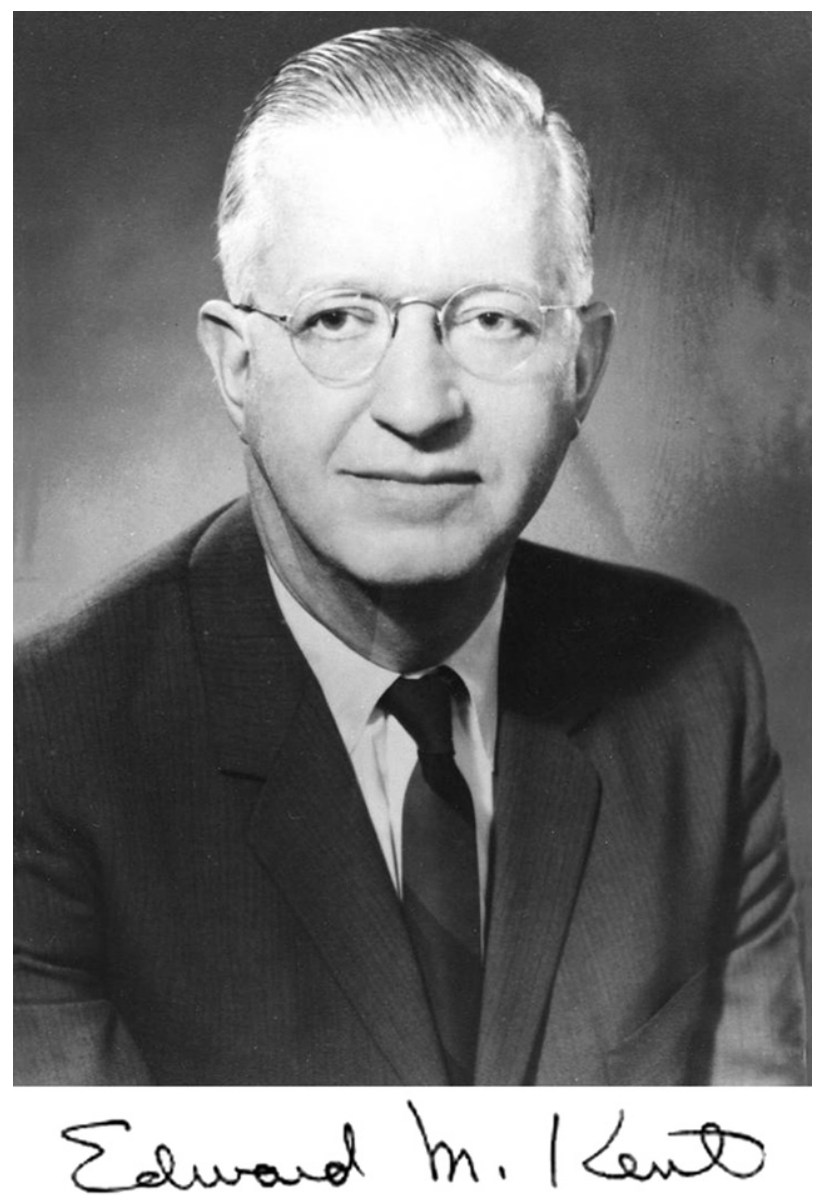

FIGURE 3. Edward Mather Kent, MD, 49th president of the American Association for Thoracic Surgery (courtesy of Allegheny General Hospital). 
TABLE 1. The American Association for Thoracic Surgery presidents receiving the Edward M. Kent, MD, Lectureship

Mortimer J. Buckley, MD

Lawrence H. Cohn, MD

Delos M. Cosgrove, MD

James L. Cox, MD

Timothy J. Gardner, MD

Irving L. Kron, MD

G. Alexander Patterson, MD

F. Griffith Pearson, MD

Craig R. Smith, MD

David J. Sugarbaker, MD

conversations with hospital friends and patients; however, he is widely considered one of the most technically proficient surgeons to ever practice in Pittsburgh. Reportedly, he was ambidextrous and required only half an hour to perform a lobectomy. ${ }^{3}$ For all these reasons, he was one of the most respected and loved surgeons in the city. He was active in local, national, and international organizations. In 1963, he organized the Pennsylvania Association for Thoracic Surgeons, a group that included such leading thoracic surgeons as John Gibbon (40th AATS president), Julian Johnson (43rd AATS president), and Henry Bahnson (57th AATS president) ${ }^{3}$

Outside the hospital, he enjoyed hunting, fishing, and trap and skeet shooting. Another passion was automobiles, specifically tinkering with and restoring the Chrysler
$300{ }^{2}$ He was married to the former Dorothy Jean Dearborn, and they had 3 children. He died June 6, 1970, while on a fishing trip, after his second myocardial infarction in 11 months. ${ }^{2}$ A portrait of Dr Kent hangs in the Department of Thoracic and Cardiovascular Surgery at Allegheny General Hospital (Figure 3), and the Edward M. Kent, MD, Lectureship is held in his honor. The recipients of this prestigious lectureship have included 10 presidents of the AATS (Table 1).

\section{References}

1. Kent EM. The president's address. J Thorac Cardiovasc Surg. 1969;58:151-7.

2. Blades B. Edward Mather Kent (1907-1970). J Thorac Cardiovasc Surg. 1971; 62:477-8.

3. Buchanan EB. Surgical teaching in Pittsburgh's Medical Schools, 1840-1990. Pittsburgh: University of Pittsburgh Medical Center; 1999.

4. Blades B, Kent EM. Individual ligation technique for lower lobe lobectomy. J Thorac Surg. 1940;10:84-101.

5. Faber LP. Individual ligation technique for lower lobe lobectomy. Ann Thorac Surg. 1990;49:1016-8.

6. Meyer JA. Individual ligation technique. Ann Thorac Surg. 1990;50:1023.

7. Stoney WS. Pioneers of cardiac surgery. Nashville: Vanderbilt University Press; 2008.

8. Magovern GJ, Cromie HW. Sutureless prosthetic heart valves. J Thorac Cardiovasc Surg. 1963;46:726-36.

9. Zlotnick AY, Shiran A, Lewis BS, Aravot D. Images in cardiovascular medicine. A perfectly functioning Magovern-Cromie sutureless prosthetic aortic valve 42 years after implantation. Circulation. 2008;117:e1-2.

10. Totaro P, Nicolardi S, Zattera G, Viganò M. Old prosthesis with a modern concept: 41-year survival with a sutureless Magovern-Cromie aortic valve prosthesis. Eur J Cardiothorac Surg. 2011;39:789.

11. Magovern GJ, Kent EM, Cushing WB. Sutureless mitral valve replacement. Ann Thorac Surg. 1966;2:474-84. 